\title{
PREDICTION OF SUBCLINICAL LEFT VENTRICULAR SYSTOLIC DYSFUNCTION BY MITRAL ANNULAR PLANE SYSTOLIC EXCURSION IN M-MODE ECHOCARDIOGRAPHY IN CORRELATION TO SPECKLE TRACKING BY 2- DIMENSIONAL ECHOCARDIOGRAPHY AND TISSUE DOPPLER IMAGING IN PATIENTS WITH TYPE 2 DIABETES MELLITUS
}

By

\author{
Mahmoud Salah Tawfik Hamza, Abd El-Halim Mohammed Abu El- \\ Magd, Sameh Emil Sadek and Wael Mohamed Attia \\ Department of Cardiology, Faculty of Medicine, Al-Azhar University (Boys-Cairo)
}

Corresponding author: Mahmoud Salah Tawfik Hamza,

E-mail: doctorhoooda97@gmail.com

\begin{abstract}
Background: Diabetes mellitus (DM) is considered as a major risk factor for heart failure with preserved Ejection fraction (EF). Using M-Mode echocardiographic method may be useful in prediction of early LV systolic dysfunction in patient with type II diabetes mellitus by measurement of mitral annular plane systolic excursion (MAPSE) in correlation to global longitudinal strain (GLS) and to tissue Doppler imaging (TDI).

Objective: To emphasize on the usefulness of M-mode echocardiographic methods like the mitral annular plane systolic excursion (MAPSE) correlated to speckle tracking by 2 dimensional (STE) and tissue Doppler imaging in prediction of subclinical LV systolic dysfunction in patients with type 2 diabetes.

Patients and methods: The study included 100 asymptomatic patients with type II DM and 50 healthy subjects as a control group. Echocardiography was performed to all of them All cases were recruited from the outpatient clinic in Maadi military Hospital in Cairo.

Results: The study included 100 asymptomatic patients with type II DM, 65 of them were females, and 50 healthy subjects as a control group, 27 of them were females. MAPSE were significantly lower in DM group [1.2 $(1.1-1.25) \mathrm{cm}$ ] compared to control group $[1.4(1.3-1.5) \mathrm{cm}](\mathrm{p}<0.001)$. MAPSE linearly had a significant positive correlation with EF, GLS and Sa wave [ $r=0.565,0.723,0.595$ respectively], $(\mathrm{p}<0.01)$. MAPSE linearly had a significant negative correlation with DM duration and HbA1C Level [ $\mathrm{r}=-0.495$, 0.776 respectively], $(\mathrm{p}<0.01)$. Average MAPSE at a cut-off point $(\leq 1.2 \mathrm{~cm})$ with good $(82 \%)$ accuracy, sensitivity $=68 \%$ and specificity $=82 \%(\mathrm{p}<0.01)$.

Conclusions: MAPSE is a useful M-mode method in prediction of subclinical LV systolic dysfunction in asymptomatic type II diabetic patients, and it has a positive correlation to GLS and Sa wave of TDI. It has a negative correlation with duration of $\mathrm{DM}$ and $\mathrm{HbA} 1 \mathrm{C}$ level.
\end{abstract}

Keywords: Subclinical Dysfunction, Diabetes Mellitus, Mitral Annular Plane Systolic Excursion, Speckle Tracking Echocardiography, Tissue Doppler imaging. 


\section{INTRODUCTION}

Diabetes mellitus (DM) is a major risk factor for heart failure with preserved Ejection fraction (HFPF) this is known as diabetic cardiomyopathy (DCM) (Cosentino et al., 2019).

Although diastolic dysfunction considered as the first hallmark of DCM, Studies highlighted that even when diastolic function is normal and LVEF is preserved, there still exists a systolic LV strain alteration assessed through longitudinal systolic LV strain and mitral annular plane Systolic Excursion (MAPSE), leading to the idea that diastolic dysfunction should not be considered the first sign of subclinical diabetic cardiomyopathy (Ernande et al., 2011).

Mitral annular plane systolic excursion (MAPSE) is a useful surrogate of left ventricular (LV) longitudinal function and has long been used as a complimentary measure for ejection fraction (EF) $(\mathrm{Hu}$ et al., 2013).

Two-dimensional speckle tracking echocardiography (2D STE) is a novel technique of cardiac imaging for assessment of cardiac movement based on frame-to-frame tracking of ultrasonic speckles in gray level 2D images it is known as a relatively angle independent technology that can determine global and regional strain (Mondillo et al., 2011).

Unlike 2D STE which is vendor, image quality and hemodynamics dependent that need more standardization and experience, MAPSE is, available in every echo machine and, feasible even in a poor image quality. So, MAPSE could be proposed as well-established clinically useful echocardiographic parameter for the assessment of LV longitudinal function and correlates with global systolic function of the LV compared to gold standard method (GLS) in patients with type II diabetes mellitus and with preserved LVEF (Hu et al., 2012 and Matos et al., 2012).

In this study, we aimed to emphasizes on the usefulness of M-mode echocardiographic methods like the mitral annular plane systolic excursion (MAPSE) correlated to speckle tracking by 2 dimensional (STE) and tissue Doppler imaging in prediction of subclinical LV systolic dysfunction in patients with type 2 diabetes.

\section{PATIENTS AND METHODS}

The study included 100 asymptomatic patients with type II DM and 50 healthy control subjects. The included cases and healthy individuals were recruited from the outpatient clinic in Maadi Military Hospital in Cairo between October 2019 and July 2020.

All patients and control group were subjected to full history taking laboratory investigations including $\mathrm{HbA} 1 \mathrm{c}$, lipid profile and 2D Transthoracic Echocardiography \& speckle tracking echocardiography.

Ejection fraction (EF) was calculated from estimation EDV and ESV using the following formula: $\mathrm{EF}=(\mathrm{EDV}-\mathrm{ESV}) /$ EDV (Modified Simpson's method). It was obtained from apical 4 (single plane) combined with apical 2 (biplane method) (Lang et al., 2015).

Pulsed wave Doppler of mitral inflow velocities were obtained to measure 
diastolic early filling velocity (E) wave and late diastolic velocity (A) wave, E/A ratio, and $\mathrm{E}$ wave. Pulsed wave TDI velocity measurements were obtained by placing the sample volume at the mitral annular level either from the septal or lateral annulus. From these recordings, myocardial systolic (Sa), early diastolic $(\mathrm{Ea})$, and $\mathrm{E} / \mathrm{Ea}$ ratio were measured and averaged (Kadappu and Thomas, 2015).

MAPSE was measured using M-mode imaging in the apical four chamber view. The M-mode cursor was placed on the septal and lateral mitral annulus parallel to the LV walls, and then both values were averaged. Measurements took place from the end of diastole, until maximal expansion in systole (Zaky et al., 1967).

GLS was measured by using 2DSTE by apical 4 chamber view, apical 2 chamber view and apical long axis view. Tracking quality was visually checked, and accepted by the operator. Strain values of LV were assessed automatically in 17 segments, and then averaged manually by the operator as mean value of each strain and presented as a bull- eye map and GLS was automatically calculated (Lang et al., 2015).

\section{Statistical Analysis:}

Data entry, processing and statistical analysis was carried out using MedCalc ver. 18.11.3 (MedCalc, Ostend, Belgium). Mean, Standard deviation ( \pm SD) and range for parametric numerical data, while Median and Inter-quartile range (IQR) for non-parametric numerical data, Frequency and percentage of non-numerical data. Tests of significance (Mann-Whitney's, Chi square tests, linear regression analysis and ROC Curve) analysis were used. Data were presented and suitable analysis was done according to the type of data (parametric and non-parametric) obtained for each variable. $\mathrm{P}$-values less than 0.05 were considered statistically significant. Mann-Whitney's Test (U test) was used to assess the statistical significance of the difference of a non-parametric variable between two study groups. Chi-Square test was used to examine the relationship between two qualitative variables. Linear regressions used in Correlations between continuous variables were presented as Pearson correlation coefficient. The ROC Curve (receiver operating characteristic) provided a useful way to evaluate the Sensitivity and specificity for quantitative Diagnostic measures that categorize cases into one of two groups.

\section{RESULTS}

The study included 100 asymptomatic patients with type II DM 65 of them were females, with age [55 (53 - 58) years]. And 50 healthy subjects as a control group 27 of them were females, with age [55 (50 - 60) years]. Comparative study between the 2 groups revealed non-significant difference as regards age and sex of the patients $(\mathrm{p}>0.05)$.

There were significant difference in serum creatinine, urea, RBS, HbA1C, albuminuria, TGs and LDL\&HDL in DM in DM cases group; compared to control group ( $\mathrm{p}<0.01$ respectively) (Table 1). 
Table (1): Comparison between the two groups as regarding demographic, clinical and laboratory data

\begin{tabular}{|c|c|c|c|c|}
\hline \multicolumn{2}{|c|}{$\begin{array}{ll}\text { Parameters } & \text { Groups } \\
\end{array}$} & $\begin{array}{c}\text { Control group } \\
(50)\end{array}$ & $\begin{array}{l}\text { DM cases group } \\
(\mathbf{1 0 0 )}\end{array}$ & $\begin{array}{c}\begin{array}{c}\text { Chi square } \\
\text { test }\end{array} \\
\text { P value }\end{array}$ \\
\hline $\begin{array}{l}\text { Gender } \\
\text { Female } \\
\text { male }\end{array}$ & & $\begin{array}{l}27(54 \%) \\
23(46 \%)\end{array}$ & $\begin{array}{l}65(65 \%) \\
35(35 \%) \\
\end{array}$ & $=0.1937$ \\
\hline \multirow{2}{*}{\multicolumn{2}{|c|}{ Variables }} & $\begin{array}{l}\text { Control group } \\
\qquad(50)\end{array}$ & $\begin{array}{l}\text { DM cases group } \\
\quad(100)\end{array}$ & $\begin{array}{c}\text { Mann- } \\
\text { Whitney's } \\
\text { U test }\end{array}$ \\
\hline & & Median (IQR) & Median (IQR) & $\mathrm{P}$ value \\
\hline \multicolumn{2}{|l|}{ Age (years) } & $55(50-60)$ & $55(53-58)$ & $=0.8182$ \\
\hline \multicolumn{2}{|l|}{ BMI } & $24.5(23.1-25.1)$ & $26.6(25.7-28.3)$ & $<0.0001$ \\
\hline \multicolumn{2}{|l|}{ SBP $(\mathrm{mmHg})$} & $115(110-$ & $130(120-135)$ & $<0.0001$ \\
\hline \multicolumn{2}{|l|}{ DBP $(\mathrm{mmHg})$} & 70( & $75(70-85)$ & $<0.0001$ \\
\hline Routine lab & $\begin{array}{l}\text { Creat. }(\mathrm{mg} / \mathrm{dL}) \\
\text { Urea }(\mathrm{mg} / \mathrm{dL}) \\
\text { RBS }(\mathrm{mg} / \mathrm{dL}) \\
\text { HbA1C }(\%) \\
\text { Albuminuria }(\mathrm{mg}) \\
\end{array}$ & $\begin{array}{c}0.7(0.7-0.8) \\
21(18-24) \\
92(87-102) \\
5.3(5.2-5.7) \\
19(17-24)\end{array}$ & $\begin{array}{c}1(0.8-1.1) \\
30.5(25-37) \\
194(184-210) \\
7.8(7.4-8.2) \\
25(21-27)\end{array}$ & $\begin{array}{l}<0.0001 \\
<0.0001 \\
<0.0001 \\
<0.0001 \\
<0.0001\end{array}$ \\
\hline Lipid profile & $\begin{array}{l}\text { T.Cholesterol(mg/dL) } \\
\text { TGs (mg/dL) } \\
\text { HDL (mg/dL) } \\
\text { LDL (mg/dL) }\end{array}$ & $\begin{array}{c}132(126-145) \\
114.5(106-124) \\
53(50-54) \\
85(75-102)\end{array}$ & $\begin{array}{c}195(185-197) \\
187(171-196) \\
42(40-46) \\
135(128-140.5)\end{array}$ & $\begin{array}{l}<0.0001 * * \\
<0.0001 * * \\
<0.0001 * * \\
<0.0001 * *\end{array}$ \\
\hline
\end{tabular}

BP: blood pressure; DM: diabetes mellitus; RBS: random blood sugar FBS: fasting blood sugar; Creat: creatinine, HDL: high density lipoprotein; LDL: low density lipoprotein; TGs: triglycerides. T. Cholesterol: total cholesterol

Regarding correlation with 2D EchoDoppler parameters; the study revealed highly significant difference in A wave [0.9 (0.84 - 0.92)] in DM cases group; compared to control group [0.65 (0.65$0.8)$ ] ( $<<0.01)$. It also revealed; highly significant difference in EF [60 (57.5 62)], E wave $[0.69(0.62-0.71)]$ and E/A ratio $[0.79(0.73-0.85)]$, in $\mathrm{DM}$ cases group; compared to control group $\mathrm{EF}$ [64 $(63-68)]$, E [0.9 (0.9 - 0.9)] E/A ratio[1.29 $(1.12-1.4)] .(\mathrm{p}<0.01$ respectively).

Regarding 2DSTE, study revealed; highly significant difference in GLS in DM cases group [-16.8 (-17.8 to -16.3$)]$; compared to control group [-22.8 (-23.1 to -21.4)] ( $\mathrm{p}<0.01)$.

Regarding MAPSE; Comparative study between the 2 groups revealed; highly significant decrease in septal, lateral and average MAPSE, in DM cases group, average [MAPSE $1.2(1.1 \quad-1.25)$ ] compared to control group [average MAPSE $1.4(1.3-1.5)](\mathrm{p}<0.05$ respectively).

Regarding TDI; study between the 2 groups revealed; highly significant difference in Aa $[0.09(0.08-0.1)]$ and E/Ea ratio [8.6 (7.7 - 9.5)] in DM cases group; compared to control group Aa $(\mathrm{m} / \mathrm{s})[0.07(0.07-0.07)] \mathrm{E} / \mathrm{Ea}$ ratio [6 (6 $-6.4)]$ ( $p<0.01$ respectively). And it also revealed; highly significant difference in $\mathrm{Sa}$ [0.08 (0.07 - 0.09)] and Ea [0.08 (0.07 0.08)] in DM cases group; compared to control group $\mathrm{Sa}[0.1(0.09-0.11)]$ and $\mathrm{Ea}[0.15(0.14-0.15)] \quad(\mathrm{p}<0.01$ respectively) (Table 2 ). 
PREDICTION OF SUBCLINICAL LEFT VENTRICULAR SYSTOLIC...

Table (2): Comparison between the 2 groups as regards Echocardiographic data using Mann-Whitney's U test

\begin{tabular}{|c|c|c|c|c|}
\hline \multirow{2}{*}{\multicolumn{2}{|c|}{ Variables $\quad$ Groups }} & $\begin{array}{c}\text { Control group } \\
(\mathbf{5 0})\end{array}$ & $\begin{array}{c}\text { DM cases group } \\
(100)\end{array}$ & $\begin{array}{c}\text { Mann- } \\
\text { Whitney's } \\
\text { U test }\end{array}$ \\
\hline & & Median (IQR) & Median (IQR) & P value \\
\hline \multirow{4}{*}{$\begin{array}{l}\text { 2D Echo- } \\
\text { Doppler }\end{array}$} & $\mathbf{E F}(\%)$ & $64(63-68)$ & $60(57.5-62)$ & $<0.0001$ \\
\hline & $\mathbf{E}(\mathrm{m} / \mathrm{s})$ & $0.9(0.9-0.9)$ & $0.69(0.62-0.71)$ & $<0.0001$ \\
\hline & $\mathbf{A}(\mathrm{m} / \mathrm{s})$ & $0.65(0.65-0.8)$ & $0.9(0.84-0.92)$ & $<0.0001$ \\
\hline & $\begin{array}{l}\text { E/A } \\
\text { ratio }\end{array}$ & $1.29(1.12-1.4)$ & $0.79(0.73-0.85)$ & $<0.0001$ \\
\hline \multirow{4}{*}{ TDI } & $\mathbf{S a}(\mathrm{m} / \mathrm{s})$ & $0.1(0.09-0.11)$ & $0.08(0.07-0.09)$ & $<0.0001$ \\
\hline & Ea $(\mathrm{m} / \mathrm{s})$ & $0.15(0.14-0.15)$ & $0.08(0.07-0.08)$ & $<0.0001$ \\
\hline & $\begin{array}{l}\mathbf{A a} \\
(\mathrm{m} / \mathrm{s})\end{array}$ & $0.07(0.07-0.07)$ & $0.09(0.08-0.1)$ & $<0.0001$ \\
\hline & $\begin{array}{l}\text { E/Ea } \\
\text { ratio }\end{array}$ & $6(6-6.4)$ & $8.6(7.7-9.5)$ & $<0.0001$ \\
\hline 2D STE & $\begin{array}{l}\text { GLS } \\
(\%)\end{array}$ & $-22.8(-23.1$ to -21.4$)$ & $-16.8(-17.8$ to -16.3$)$ & $<0.0001$ \\
\hline \multirow{3}{*}{ MAPSE } & $\begin{array}{l}\text { Septal } \\
\text { MAPSE } \\
(\mathrm{cm})\end{array}$ & $1.3(1.3-1.4)$ & $1.2(1.1-1.2)$ & $<0.0001$ \\
\hline & $\begin{array}{l}\text { Lateral } \\
\text { MAPSE } \\
(\mathrm{cm})\end{array}$ & $1.5(1.4-1.6)$ & $1.2(1.1-1.3)$ & $<0.0001$ \\
\hline & $\begin{array}{l}\text { Average } \\
\text { MAPSE } \\
(\mathrm{cm})\end{array}$ & $1.4(1.3-1.5)$ & $1.2(1.1-1.25)$ & $<0.0001$ \\
\hline
\end{tabular}

A: late diastolic velocity, Aa: late diastolic annular velocity, E: early diastolic velocity, Ea: early diastolic annular velocity, EF: ejection fraction, GLS: global longitudinal strain, MAPSE: mitral annular plane systolic excursion, Sa: systolic annular velocity. 


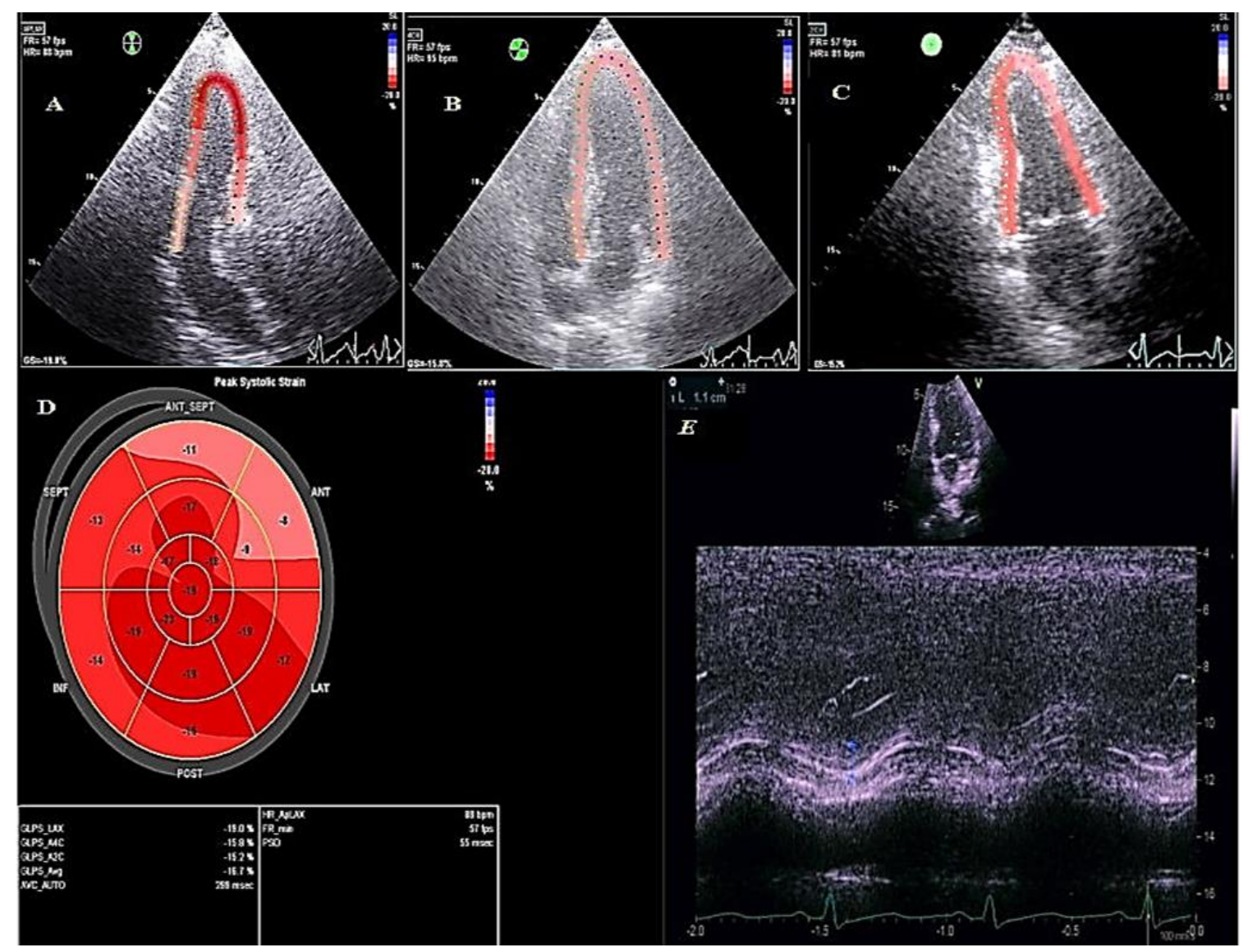

Figure (1): 2D-speckle tracking echocardiography images for a diabetic Case, showing longitudinal strain in different segments of $L V$ in apical 4,2,3 chamber views (image $A, B, C$ respectively) and the Bull's eye showing the reduced global longitudinal strain (image $D$ ), the last image $E$ shows MAPSE of the same patient at the lateral mitral annulus

On correlation analysis by applying linear regression analysis we found that MAPSE linearly had a significant positive correlation with EF, GLS and Sa wave [r= $0.565,0.723,0.595$ respectively]. ( $\mathrm{p}<$
0.01). But it was linearly had a significant negative correlation with DM duration and HbA1C Level[ $\mathrm{r}=-0.495, \quad-0.776$ respectively] ( $\mathrm{p}<0.01)$ (Table 3 and fig. $2)$.

Table (3): Linear correlation analysis between MAPSE and GLS, Sa, DM \& HbA1C.

\begin{tabular}{|c|c|c|}
\hline Associated & $\mathbf{r}$ & $\mathbf{P}$ \\
\hline MAPSE Factor & 0.565 & $<0.0001^{* *}$ \\
\hline GLS & 0.723 & $<0.0001^{* *}$ \\
\hline Sa wave & 0.595 & $<0.0001^{* *}$ \\
\hline DM duration & -0.495 & $<0.0001^{* *}$ \\
\hline HbA1C & -0.776 & $<0.0001^{* *}$ \\
\hline
\end{tabular}



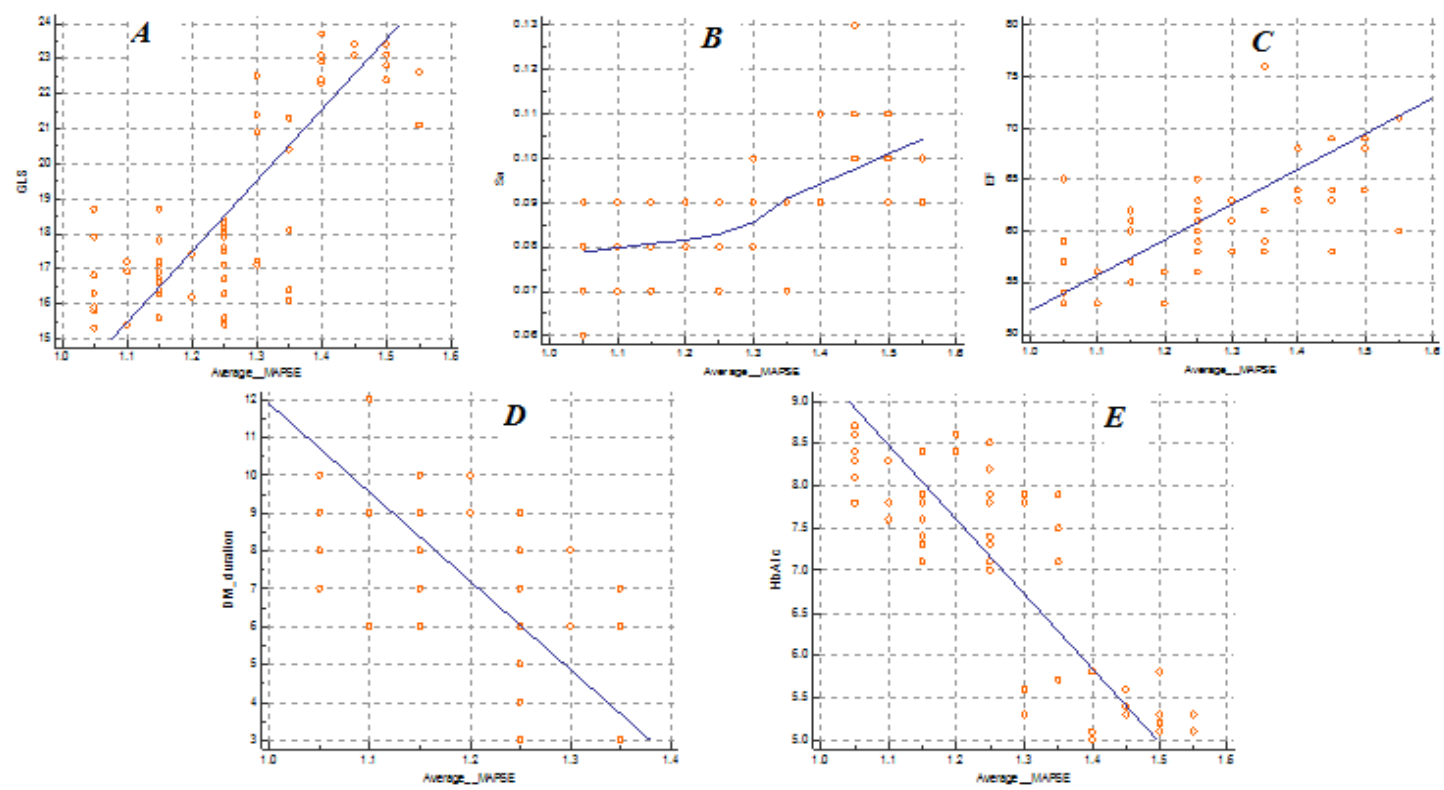

Figure (2):Linear regression curves between MAPSE and GLS, Sa, DM \& HbA1C $A=$ MAPSE and GLS., $B=$ MAPSE and $S a, C=$ MAPSE and EF. $D=$ MAPSE and DM duration, E=MAPSE and. HbA1c

Comparing between sensitivity and specificity of MAPSE and other echocardiographic modality in detection of subclinical LV dysfunction by using ROC Curve (Table 4).

Table (4): Roc-curve of MAPSE, E/Ea\& Sa to predict patients with Subclinical LVSD

\begin{tabular}{|l|c|c|c|c|c|c|}
\hline Variable & AUC & SE & $\begin{array}{c}\text { Best Cut off } \\
\text { point (Criterion) }\end{array}$ & $\begin{array}{c}\text { Sensitivity } \\
(\mathbf{\%})\end{array}$ & $\begin{array}{c}\text { Specificity } \\
(\mathbf{\%})\end{array}$ & P value \\
\hline E/Ea ratio & 0.760 & 0.0401 & $>7$ & 92.59 & 59.38 & $<0.0001^{* *}$ \\
\hline $\begin{array}{l}\text { Average } \\
\text { MAPSE }\end{array}$ & 0.820 & 0.0341 & $\leq 1.2$ & 68.52 & 82.29 & $<0.0001^{* *}$ \\
\hline Sa wave & 0.681 & 0.0433 & $\leq 0.09$ & 100 & 28.12 & $<0.0001^{* *}$ \\
\hline
\end{tabular}

To measure the sensitivity and specificity of MAPSE for predicting subclinical left ventricular systolic dysfunction in type II diabetic patients, the ROC curve was applied.Average MAPSE at a cut-off point $(\leq 1.2 \mathrm{~cm})$ with good $(82 \%)$ accuracy, sensitivity $=68 \%$ and specificity $=82 \% \quad(\mathrm{p}<0.01)$. when compared to the GLS in prediction of subclinical dysfunction.E/Ea ratio at a cutoff point $(>7)$ predicted patients with Subclinical LVSD, with fair (76\%) accuracy, sensitivity $=92 \%$ and specificity $=59 \%(\mathrm{p}<0.01)$. Sa wave at a cutoff point $(\leq 0.09 \mathrm{~m} / \mathrm{s})$ predicted patients with Subclinical LVSD, with fair $(70 \%)$ accuracy, sensitivity $=100 \%$ and specificity $=28 \%(\mathrm{p}<0.01)($ Figure 3). 

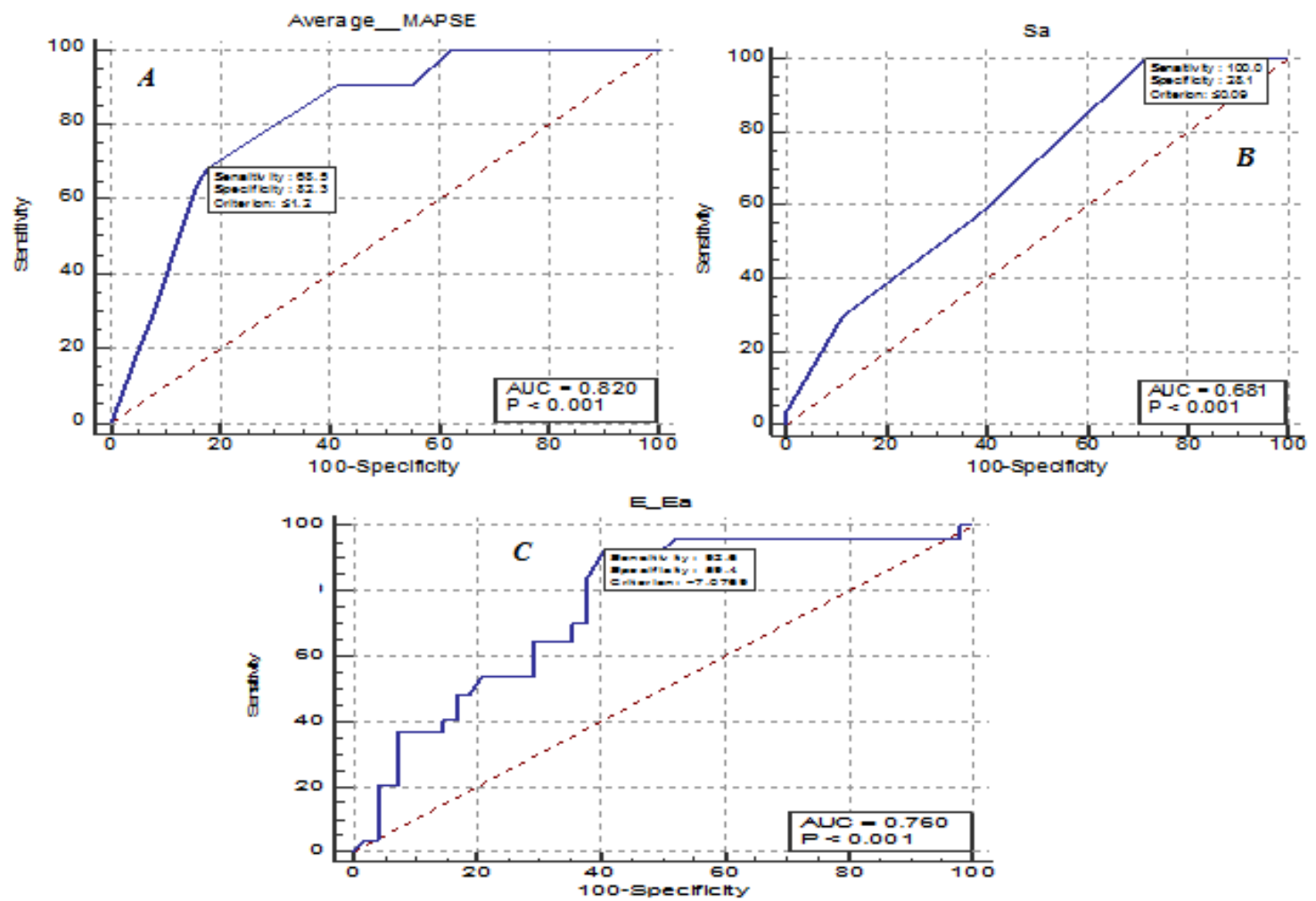

Figure (3): Roc-curve of MAPSE, E/Ea \& Sa to predict patients with Subclinical LVSD

\section{$A=$ ROC curve of MAPSE, $B=$ ROC curve of $E / E$ a ratio, $C=R O C$ curve of $S$ wave}

\section{DISCUSSION}

Our case-control study revealed a significant decrease in average MAPSE, in DM cases group compared to control group with average MAPSE at a cut-off point $(\leq 1.2)$ predicted patients with Subclinical LVSD, with good $(82 \%)$ accuracy, sensitivity $=68 \%$ and specificity $=82 \%$. also, Linear correlation analysis showed that, EF had a significant positive correlation with MAPSE. This was in agreement with Loncarevic et al. (2016) who found that MAPSE were significantly lower in all patients with DM compared to control.

Our study disagreed with Grue et al. (2018) who studied that mitral annular plane systolic excursion $\leq 10 \mathrm{~mm}$ detected left ventricular dysfunction with $82 \%$ specificity, $76 \%$ specificity, $56 \%$ positive predictive value and $92 \%$ negative predictive value. This discrepancy might be a result of different sample size and also due to study population including patients with systolic and diastolic dysfunction which might lower the results.

In our study, regarding linear correlation of MAPSE with the GLS, there was a strong correlation between MAPSE and longitudinal strain. Linear correlation analysis showed that; GLS had a significant positive correlation with MAPSE. This was in agreement with Wenzelburger et al. (2011) who found that, at rest MAPSE correlated with longitudinal strain and on exercise with longitudinal strain. Huang et al. (2017) also found that longitudinal strain was 
significantly lower in diabetes patients as compared to the control.

Our case-control study revealed significant difference in GLS in DM cases group compared to control group with significant positive correlation with MAPSE. $54 \%$ of DM patients with preserved LVEF had LV longitudinal systolic dysfunction determined as GLS < $17.1 \%$. This was in agreement with Ernande et al. (2011) who found that $23 \%$ of DM patients with preserved LVEF had LV longitudinal systolic dysfunction determined as GLS < 18\%. Zoroufian et al. (2014) reported a significant reduction in longitudinal strain of $\mathrm{LV}$ in diabetic patients with evidence of diastolic dysfunction and in those with normal LV filling compared to the control.

In our study, regarding linear correlation with the Sa and tissue Doppler systolic annular velocity provided a sensitive tool for detection of the global longitudinal LV function. Our casecontrol study revealed significant difference in Sa wave in DM cases group comparing to control group with significant positive correlation with MAPSE. By using ROC-curve analysis, Sa wave at a cut-off point $(\leq 0.09 \mathrm{~m} / \mathrm{s})$ predicted patients with Subclinical LVSD, with fair (70\%) accuracy, sensitivity= $100 \%$ and specificity $=28 \%$. It also revealed significant difference in $\mathrm{E} / \mathrm{Ea}$ ratio, in DM cases group compared to control group. E/Ea ratio at a cut-off point $(>7 \mathrm{~m} / \mathrm{s})$ predicted patients with Subclinical LVSD, with fair (76\%) accuracy, $\quad$ sensitivity $=92 \%$ and specificity $=59 \%$.
Dalen et al. (2010) found that mean \pm SD systolic mitral annular velocities (Sa) were $8.2 \pm 1.3 \mathrm{~cm} / \mathrm{s}$ in women and $8.6 \pm 1.4 \mathrm{~cm} / \mathrm{s}$ in men. From et al. (2010) concluded that pre-clinical diastolic dysfunction is prevalent in patients with DM with increase in the $\mathrm{E} / \mathrm{e}^{\prime}$ ratio in diabetic patients which was associated with subsequent $\mathrm{HF}$ and mortality independent of hypertension, coronary disease, and other echocardiographic parameters. Grue et al. (2018) found that MAPSE $\leq 10 \mathrm{~mm}$ could detect left ventricular dysfunction. with $82 \%$ sensitivity and $76 \%$ specificity. Cut of value of Sa wave $\leq 5.4 \mathrm{~cm} / \mathrm{s}$ with $83 \%$ sensitivity $68 \%$ specificity. The discrepancy might be attributed to gain settings and, misalignment of the ultrasound beam will cause under estimation of the measurement in the Doppler spectrum of the tissue velocity.

In Our study through linear correlation analysis it has been shown that there was a negative correlation between longitudinal strain and plasma level of HBA1C and duration of diabetes. Therefore, the better control of DM may delay the progression of cardiac pathology. Many studies are recommended to strength this issue. Elgohary et al. (2017) reported significant statistical difference in GLS in patients with longer diabetic duration and concluded that, diabetic duration was strongly correlated with reduction of global longitudinal strain (LS).

\section{CONCLUSION}

MAPSE is considered a useful Mmode method in prediction of subclinical LV systolic dysfunction in asymptomatic type II diabetic patients and it has positive correlation to GLS \& Sa wave of TDI. it 
has a negative correlation with duration of DM and HbA1C Level.

\section{REFERENCES}

1. Cosentino F, Peter J, Victor A, Clifford J, Antonio C, Victoria D, Massimo F and Gerasimos F. (2019): ESC Guidelines on diabetes, prediabetes, and cardiovascular diseases developed in collaboration with the EASD: The Task Force for diabetes, pre-diabetes, and cardiovascular diseases of the European Society of Cardiology (ESC) and the European Association for the Study of Diabetes (EASD). European Heart Journal, 41: 255-323.

2. Dalen H, Anders T, Lars J, Svein A and Asbjorn S. (2010): Reference values and distribution of conventional echocardiographic Doppler measures and longitudinal tissue Doppler velocities in a population free from cardiovascular disease. Circulation Cardiovascular Imaging, 3: 614-22.

3. Elgohary AA, Mohamed AS, Ragab AM and Mohamed GM. (2017): Cardiac imaging-Echocardiography] Effect of Diabetic Duration on Left Ventricular Global Longitudinal Strain by Speckle Tracking Imaging. American Journal of Cardiology, 119: 6-12.

4. Ernande L, Cyrille B, Ernst RR, Marc LD, Hélène $T$, Pierre Gand Philippe M (2011): Diastolic dysfunction in patients with type 2 diabetes mellitus: is it really the first marker of diabetic cardiomyopathy?, Journal of the American Society of Echocardiography, 24: 1268-75.
5. From AM, Christopher GS and Horng HC (2010): The Development of Heart Failure in Patients with Diabetes Mellitus and Pre-Clinical Diastolic Dysfunction. A PopulationBased Study, 55: 300-05.

6. Grue JF, Sigurd S, Håvard D, Øyvind S, Ole CM, Stein OS, Hans T and Bjørn OH (2018): Automatic measurements of mitral annular plane systolic excursion and velocities to detect left ventricular dysfunction. Ultrasound in Medicine \&Biology, 44: 168-76.

7. Hu K, Dan L, Sebastian H, Markus N, Philipp DG, Wolfram V, Georg E, Bart B and Frank W. (2012): Clinical implication of mitral annular plane systolic excursion for patients with cardiovascular disease. European Heart Journal - Cardiovascular Imaging, 14: 205-12.

8. Huang SJ, Iris T, Andrea MH, Michel S and Anthony SM. (2017): Longitudinal wall fractional shortening: an M-mode index based on mitral annular plane systolic excursion (MAPSE) that correlates and predicts left ventricular longitudinal strain (LVLS) in intensive care patients. Critical care (London, England), 21: 292-92.

9. Kadappu KK and Thomas L. (2015): Tissue Doppler imaging in echocardiography: value and limitations. Heart, Lung and Circulation, 24: 224-33.

10. Lang RM, Luigi PB, Victor $M$, Afilalo J, Armstrong A, Ernande L, Flachskampf FA, Foster E, Goldstein SA and Kuznetsova T. (2015): 
Guidelines and standards. Recommendations for cardiac chamber quantification by echocardiography in adults: an update from the American Society of Echocardiography and the European Association of Cardiovascular Imaging. Journal of the American Society of Echocardiography, 28(1):1-39.

11. Loncarevic B, Trifunovic D, Soldatovic I and Vujisic-Tesic B (2016): Silent diabetic cardiomyopathy in everyday practice: a clinical and echocardiographic study. BMC Cardiovascular Disorders, 16:242-249.

12. Matos J, Itzhak $K$, Georgia $P$ and Gila P. (2012): Mitral annular plane systolic excursion as a surrogate for left ventricular ejection fraction. Journal of the American Society of Echocardiography, 25: 969-74.
13. Mondillo S, Maurizio G, Donato M, Matteo C, Vincenzo SL, Valerio Z, Piercarlo B, Antonello D, Denisa $M$ and Mariangela L. (2011): Speckle-tracking echocardiography: a new technique for assessing myocardial function', Journal of Ultrasound in Medicine, 30: 71-83.

14. Wenzelburger FWG, Yu TT, Ferrah JC, Eveline SPL, Francisco L and John ES. (2011): Mitral annular plane systolic excursion on exercise: a simple diagnostic tool for heart failure with preserved ejection fraction', European journal of heart failure. 13: 953-60.

15. Zaky A, Grabhorn $L$ and Harvey F. (1967): Movement of the mitral ring: a study in ultra sound cardiography. Cardiovascular Research, 1: 121-31. 
توقع الإعتلال في وظليفة البطين الأيسر الاثقباضي بواسطة قياس

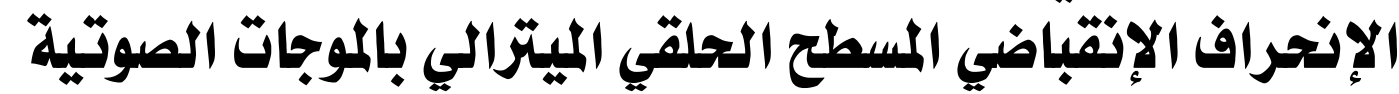

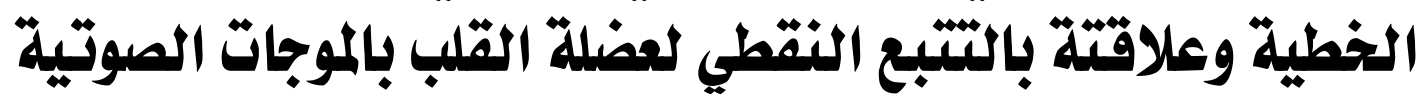

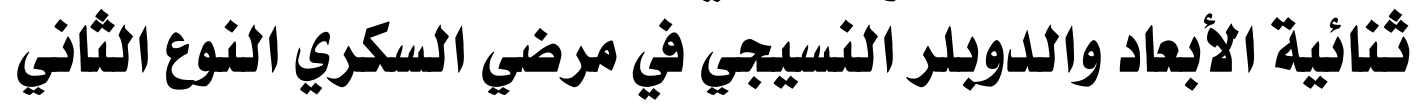

محمود صلاح توفيق حمزة، عبد الحليم محمد ابو المجد، سامح اميل صادق، و ائل محمد عطية

قسم أمراض القلب بكلية الطب جامعة الأزهر (بنين- القاهرة)

E-mail: doctorhoooda97@gmail.com

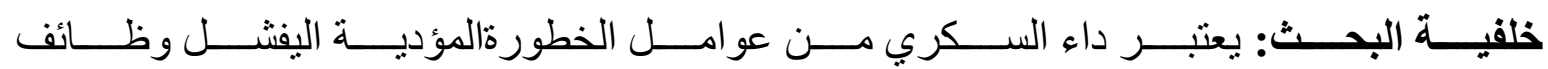

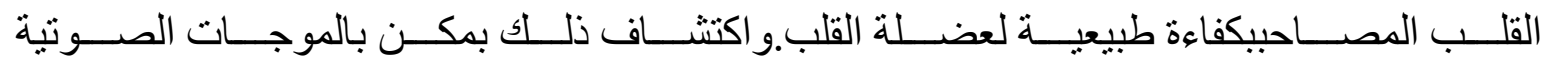

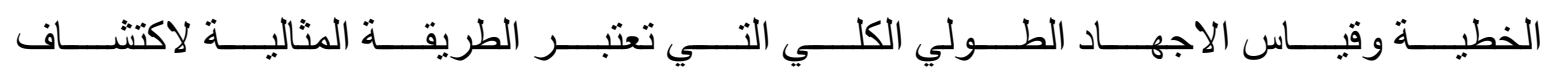
الاعتلال في وظائف البطين الايسر الانقباضي بين مرضي السكري.

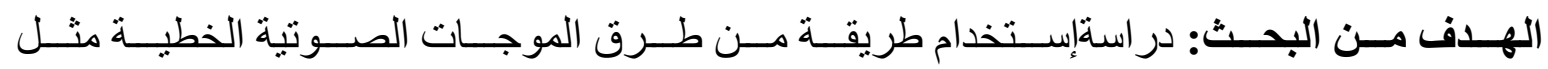

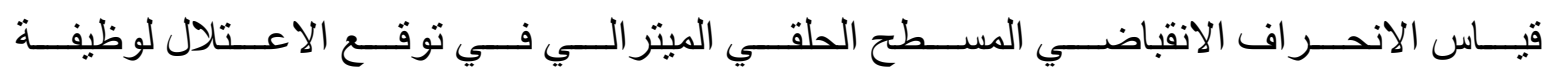

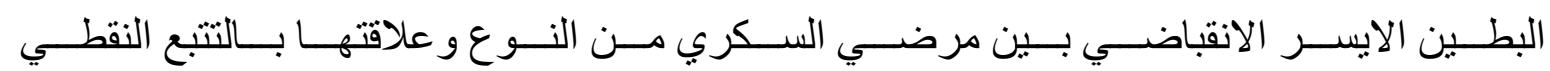
لعضلة القلب بالموجات الصوتية ثنائية الابعاد و الدوبلر النسيجي الثاني.

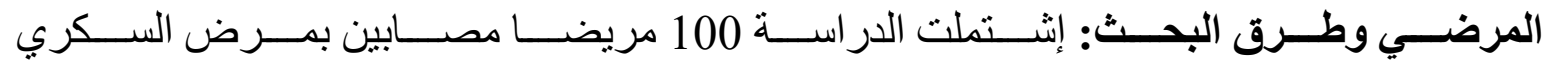

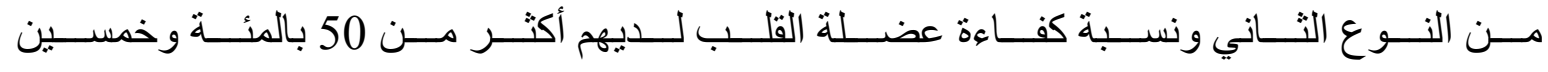

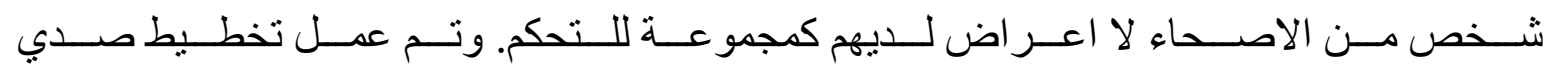

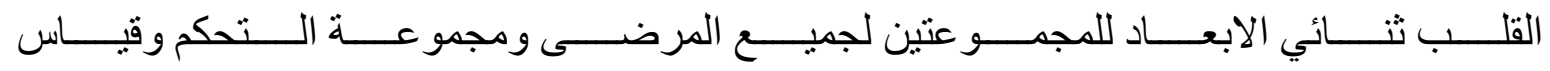

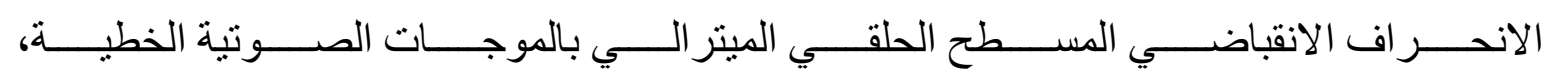

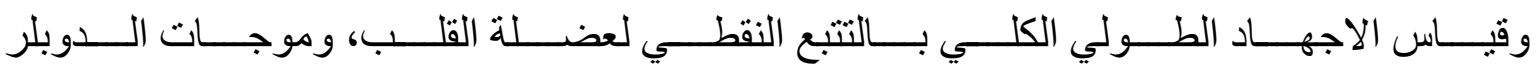
النسيجي.

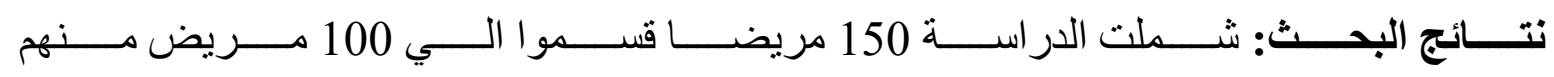

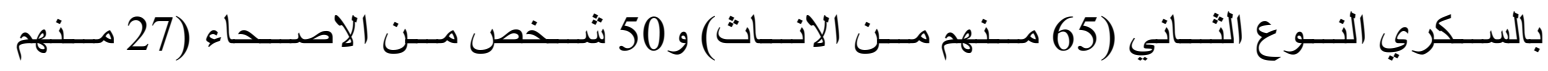




\section{PREDICTION OF SUBCLINICAL LEFT VENTRICULAR SYSTOLIC...}

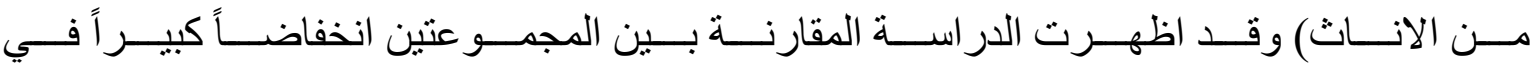

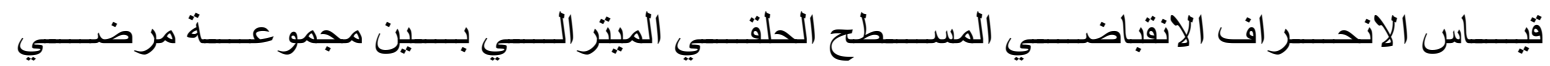

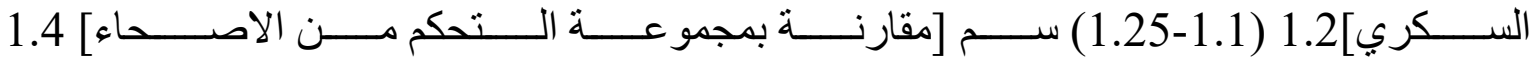

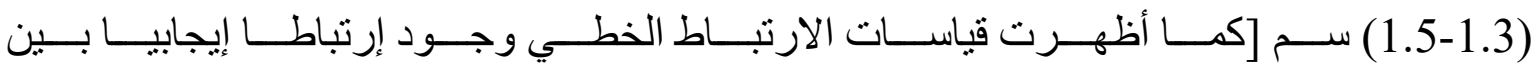

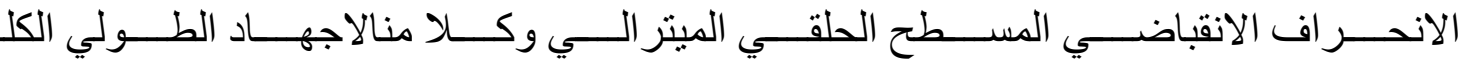

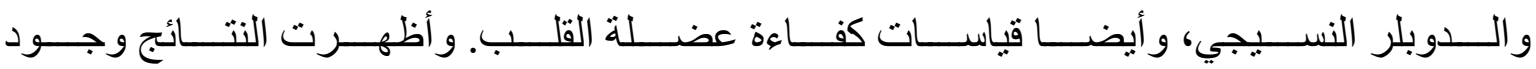

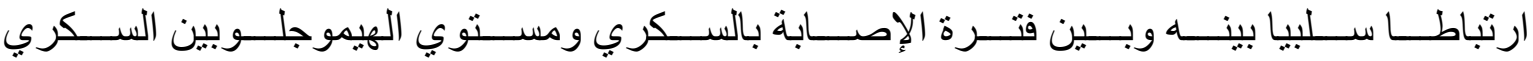

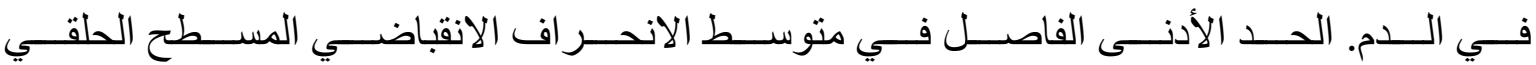

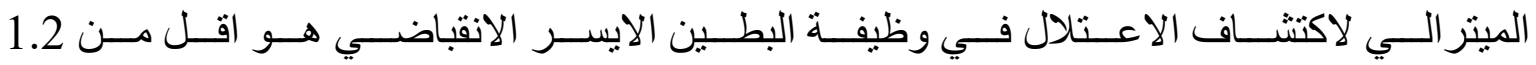
سمبدقة جيدة (82\%) وحساسية (68\%) وخصوصية (82\%).

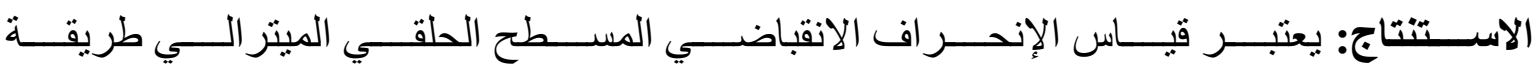

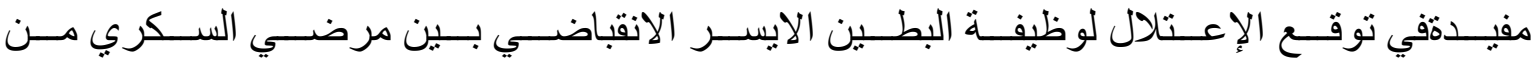

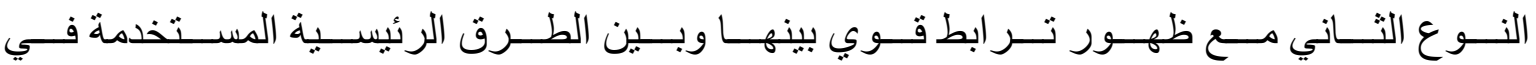
التشخيص مثل الإجهاد الطولي الكلي و الدوبلر النسيجي. الكلمــات الدالــة: الإعــتلال فــي وظيفــة البطــين الأيســر الانقباضــي، مــرض الســكري،

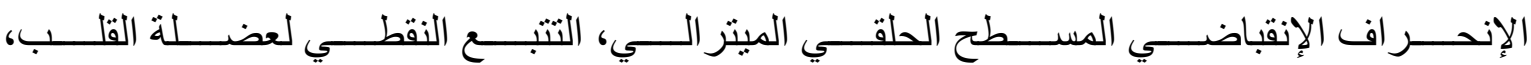
و الدوبلر النسيجي. 